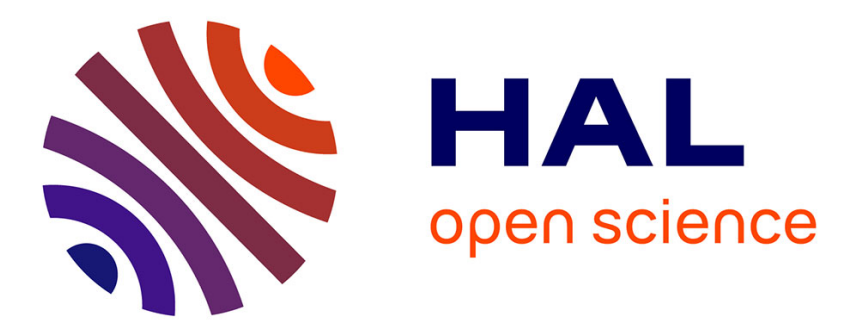

\title{
Inhibition of nitrogenase by oxygen in marine cyanobacteria controls the global nitrogen and oxygen cycles
}

I. Berman-Frank, Y.-B. Chen, Y. Gerchman, G. C. Dismukes, P. G. Falkowski

\section{- To cite this version:}

I. Berman-Frank, Y.-B. Chen, Y. Gerchman, G. C. Dismukes, P. G. Falkowski. Inhibition of nitrogenase by oxygen in marine cyanobacteria controls the global nitrogen and oxygen cycles. Biogeosciences Discussions, 2005, 2 (2), pp.261-273. hal-00297738

\section{HAL Id: hal-00297738 \\ https://hal.science/hal-00297738}

Submitted on 15 Mar 2005

HAL is a multi-disciplinary open access archive for the deposit and dissemination of scientific research documents, whether they are published or not. The documents may come from teaching and research institutions in France or abroad, or from public or private research centers.
L'archive ouverte pluridisciplinaire HAL, est destinée au dépôt et à la diffusion de documents scientifiques de niveau recherche, publiés ou non, émanant des établissements d'enseignement et de recherche français ou étrangers, des laboratoires publics ou privés. 
Nitrogenase controls

\section{Inhibition of nitrogenase by oxygen in marine cyanobacteria controls the global nitrogen and oxygen cycles}

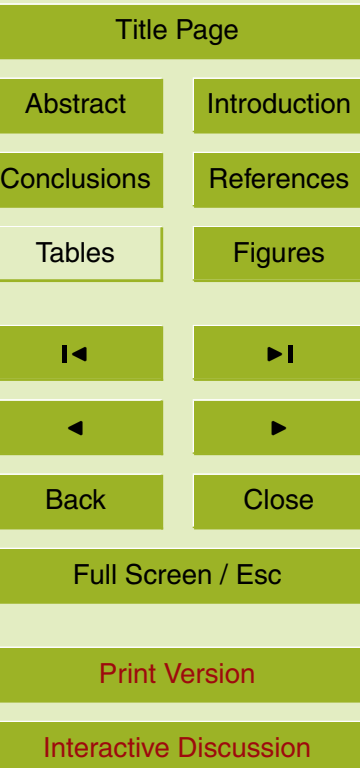

Correspondence to: I. Berman-Frank (irfrank@mail.biu.ac.il)

Interactive Discussion

(C) 2005 Author(s). This work is licensed under a Creative Commons License. 


\section{Abstract}

Cyanobacterial $\mathrm{N}_{2}$-fixation supplies the vast majority of biologically accessible inorganic nitrogen to nutrient-poor aquatic ecosystems. The process, catalyzed by the heterodimeric protein complex, nitrogenase, is thought to predate that of oxygenic 5 photosynthesis. Remarkably, while the enzyme plays such a critical role in Earth's biogeochemical cycles, the activity of nitrogenase in cyanobacteria is markedly inhibited in vivo at a post-translational level by the concentration of $\mathrm{O}_{2}$ in the contemporary atmosphere leading to metabolic and biogeochemical inefficiency in $\mathrm{N}_{2}$ fixation. We illustrate this crippling effect with data from Trichodesmium spp. an important contributor of "new nitrogen" to the world's subtropical and tropical oceans. The enzymatic inefficiency of nitrogenase imposes a major elemental taxation on diazotrophic cyanobacteria both in the costs of protein synthesis and for scarce trace elements, such as iron. This restriction has, in turn, led to a global limitation of fixed nitrogen in the contemporary oceans and provides a strong biological control on the upper bound of oxygen 15 concentration in Earth's atmosphere.

\section{Introduction}

Only a small fraction of prokaryotic organisms from the bacterial and archaeal domains can procure and utilize atmospheric nitrogen by reducing it to ammonia. This process is critical in supplying nitrogen for further biological activity in $\mathrm{N}$-limited environments

such as many regions of the modern oceans. Investment in nitrogen fixation is an expensive metabolic process which demands large inputs and maintenance requirements of energy, reducing power, antioxidant enzymes and metal co-factors such as iron and Mo (Raven, 1988; Kustka et al., 2003). Moreover, biological nitrogen fixation, and specifically the nitrogenase enzyme, is notorious for its sensitivity to molecular oxygen. Nitrogenase consists of two proteins, the iron protein containing a single $\mathrm{Fe}_{4} \mathrm{~S}_{4}$ cluster bound between subunits, and the iron-molybdenum protein composed of two types of
BGD

2, 261-273, 2005

Nitrogenase controls $\mathrm{N}$ and $\mathbf{O}$ cycles

I. Berman-Frank et al.

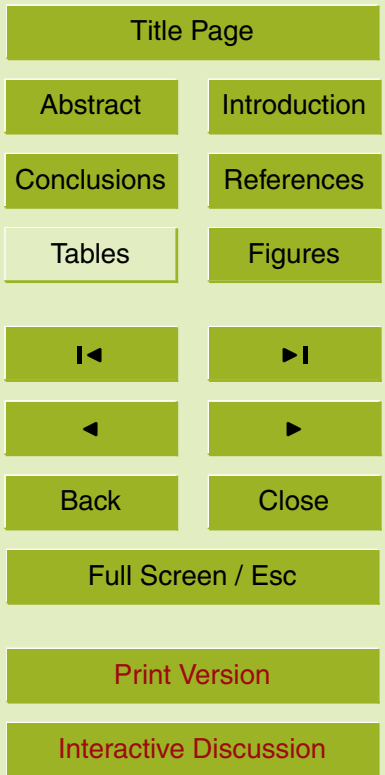

EGU 
clusters, the P cluster and the FeMoco center (sometimes called the M cluster) which is the site of $\mathrm{N}_{2}$ reduction. Whereas both the $\mathrm{Fe}_{4} \mathrm{~S}_{4}$ and $\mathrm{P}$ clusters are inactivated by $\mathrm{O}_{2}$, the $\mathrm{Fe}_{4} \mathrm{~S}_{4}$ cluster is much more susceptible and irreversibly damaged in vitro (Burgess and Lowe, 1996). Moreover, high oxygen stress causes proteolysis of nitro5 genase subunits (Durner et al., 1996), suppresses nitrogenase synthesis, and leads to a shortage of respiratory substrates and reductants necessary for nitrogen fixation and assimilation (Gallon, 1992). Inhibitory effects of moderate levels of oxygen, or short exposure times, in vivo may be reversed, leading to an increase in nitrogen fixation rates (Prosperi, 1994; Ludden and Roberts, 1995; Pan and Vessey, 2001; Yakunin et 10 al., 2001) and, in some diazotrophs, post-translational modification of the Fe protein from an inactive to active form (Sweet and Burris, 1982; Jouanneau et al., 1983; Ernst et al., 1990; Ohki et al., 1991; Zehr et al., 1993). The level of resistance to oxygen stress and the mechanisms involved vary between diazotrophs (Gallon, 1992; Tuli et al., 1996; Berman-Frank et al., 2003). Furthermore, diazotrophic cyanobacteria, which provide the bulk of fixed nitrogen to the surface oceans, are the only diazotrophs that actively produce oxygen via photosynthesis and must contend with further restrictions on the nitrogen (Gallon, 1992; Tuli et al., 1996; Bergman et al., 1997; Berman-Frank et al., 2003). Thus, nitrogenase in the real-world operates at only a fraction of its potential activity, yet is a major elemental taxation on diazotrophic cyanobacteria both for scarce trace elements, such as iron, and in the costs of protein synthesis. These taxes have, in turn, led to a global limitation of fixed nitrogen in the oceans (Falkowski, 1997). We examine these constraints with data from the bloom-forming marine cyanobacterium Trichodesmium IMS101 which contributes significantly to nitrogen fixation in the tropical and sub-tropical oceans.
BGD

2, 261-273, 2005

Nitrogenase controls $\mathrm{N}$ and $\mathrm{O}$ cycles

I. Berman-Frank et al.

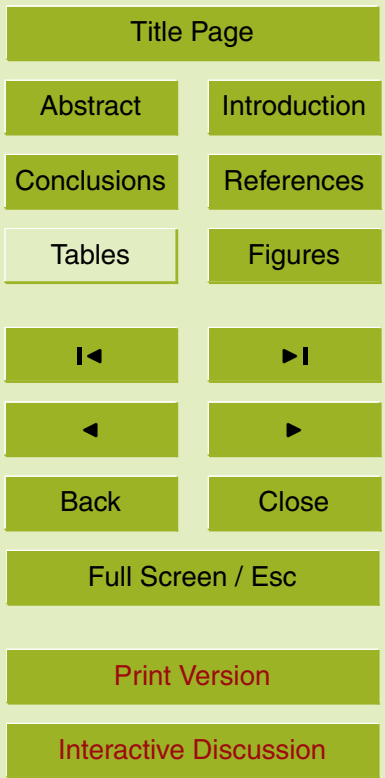

EGU 


\section{Materials and methods}

\subsection{Culture growth conditions}

Trichodesmium IMS101 cultures were grown and maintained as described previously (Berman-Frank et al., 2001b). Oxygen concentrations were adjusted according to re5 quirement, supplemented with ambient $\mathrm{CO}_{2}$ concentrations $(0.035 \%)$ and a balance of nitrogen gas and bubbled into the cultures at a saturating rate for the necessary experimental duration.

\subsection{Nitrogenase activity}

Nitrogen fixation rates for Trichodesmium were measured as described previously 10 (Berman-Frank et al., 2001a) using the acetylene reduction method according to Capone (Capone, 1993). Ethylene production was measured on a SRI 310 gas chromatograph with a flame ionization detector and quantified relative to an ethylene standard. Results were normalized to carbon and chlorophyll.

\subsection{Western blots}

15 Proteins were extracted according to Chen et al. (1998), and separated by sodium dodecyl sulfate-polyacrylamide gel electrophoresis on $8-16 \%$ gradient gels (Gradipore iGels). After transfer to a polyvinylidend difluoride membrane (PVDF - Millipore), the proteins were challenged with antisera raised against the Fe protein of nitrogenase (generously provided by P. Ludden, U.California Berkley) conjugated to IgG HRP and

\subsection{RNA analysis}

RNA extraction and northern analysis were carried out based on methods described previously (Chen et al., 1999). Briefly, equal volume of from each treatment were fil-
BGD

2, 261-273, 2005

Nitrogenase controls $\mathrm{N}$ and $\mathrm{O}$ cycles

I. Berman-Frank et al.

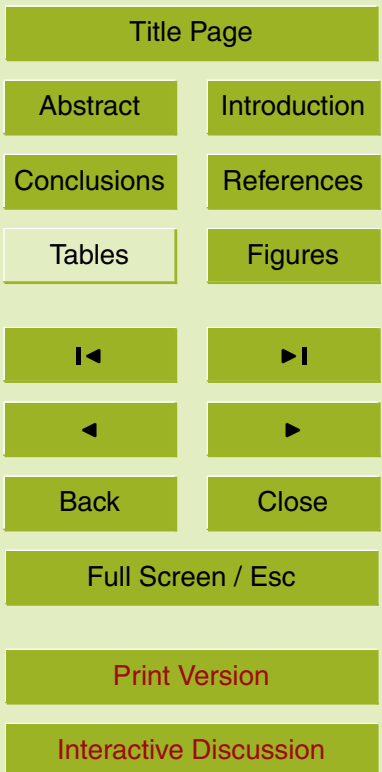

EGU 
tered and immediately lysed in RNA extraction buffer (5\% Triton X-100, 10\% sucrose, $20 \mathrm{mM}$ EDTA, $50 \mathrm{mM}$ Tris, $100 \mathrm{mM}$ DTT). The subsequent total RNA processing was performed following commonly used phenol/chloroform extraction protocols. Northern blot analyses were carried out following widely used protocols with some modifications 5 (Chen et al., 1999). Total RNA extracted from equal amounts of biomass was fractionated by electrophoresis on a $1 \%$ agarose gel with $1 \mathrm{M}$ formaldehyde. The RNA was then transferred to a charged nylon membrane (Nytran, Schleicher \& Schuell) using a TurboBlottor System (S \& S). All Northern blots were initially hybridized to a specific nifH probe. Probes were labeled with $\alpha^{32} \mathrm{P}$-dATP using Promega Prime-A-Gene La10 beling System. All hybridization was performed using Ambion PerfectHyb system. The blots were washed twice with $0.2 \times$ SSC and $0.1 \%$ SDS, followed by $30 \mathrm{~min}$ incubation at $42^{\circ} \mathrm{C}$ before being exposed to Kodak BioMax MR/MS films.

\section{Results and discussion}

To highlight the effect of $\mathrm{O}_{2}$ concentration on the cost of nitrogen fixation in cyanobacte15 ria, we illustrate these restrictions with data from the bloom-forming marine cyanobacterium Trichodesmium IMS101. Trichodesmium is a colonial, non-heterocystous diazotroph which separates oxygenic photosynthesis and nitrogen fixation spatially and temporally within the photoperiod (Berman-Frank et al., 2001b). Sequence and structural analyses of its nitrogenase are similar to those of other organisms (Zehr et al., 20 1997a). Previous work showed that nitrogenase inhibition by oxygen may be reversed when cells are exposed for short ( $30 \mathrm{~min})$ periods to oxygen levels of $40 \%$ or lower (Zehr et al., 1993). This quick response to both activation and inhibition indicates that new transcription and synthesis of the nitrogenase protein are not essential for enhanced activity and that constitutive protein levels are present that can be "turned-on" when oxygen concentrations are lowered.

We verified this by assaying the abundance of nifHDK transcripts and the corresponding gene product in Trichodesmium cultures incubated for $5 \mathrm{~h}$ with $0,5,21$

\section{Nitrogenase controls} $\mathrm{N}$ and $\mathrm{O}$ cycles

I. Berman-Frank et al.

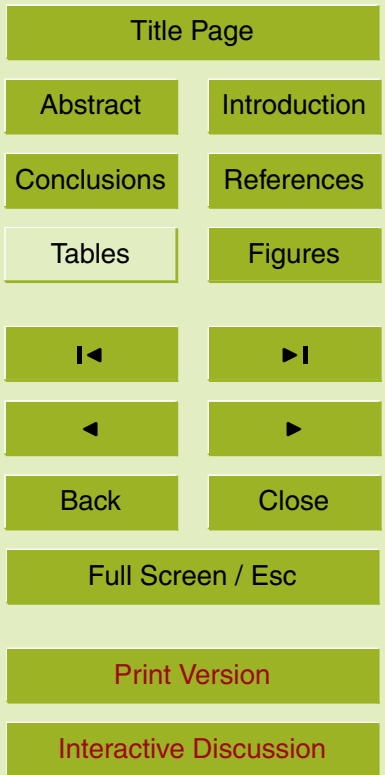


(present atmospheric level - PAL), and $50 \% \mathrm{O}_{2}$ (Fig. 1). Incubations were performed after circadian- controlled daily transcription began. The results indicate that extracellu$\operatorname{lar} \mathrm{O}_{2}$ does not significantly influence gene transcription or protein synthesis of nitrogenase on this time scale except at very high (50\%) oxygen concentrations (Figs. 1a and 5 1b). In contrast, nitrogenase activity was strongly depressed by PAL and higher levels of $\mathrm{O}_{2}$; at $50 \% \mathrm{O}_{2}>90 \%$ of the nitrogenase activity was inhibited within $1 \mathrm{~h}$ (Fig. 1c).

The limited sensitivity of nifHDK transcription, and nitrogenase protein to oxygen concentrations was previously observed in Trichodesmium (Dominic et al., 1998) and other cyanobacterial diazotrophs which exhibit a similar behavior. In Anabaena sp. 10 PCC 7120 oxygen concentration required to repress nifHDK transcription was greater than that required to destroy nitrogenase activity (Elhai and Wolk, 1991). In Gloeothece sp. and Oscillatoria limosa high oxygen stress did not repress protein synthesis of nitrogenase (Gallon, 1992).

In Trichodesmium, as in other diazotrophs (Sweet and Burris, 1982; Jouanneau et 15 al., 1983; Hallenbeck, 1992), a modification of nitrogenase Fe-protein, distinguishes an active and an inactive form of the protein (Ohki et al., 1991; Zehr, 1993; Chen, 1998). Our results concur with other studies that the total amount of nitrogenase Fe-protein does not change rapidly in response to reduced oxygen and only when oxygen levels were very high $(50 \%)$ did the protein abundance decrease. Addition of the proteinsynthesis inhibitor, chloramphenicol (CAMP), for $4 \mathrm{~h}$ resulted in demonstratively little change in protein levels under all oxygen concentrations (results not shown),

Post-translational modification of activity appears relatively common in diazotrophic cyanobacteria and operates at much lower concentrations of oxygen then those required for repression of nif genes (Tuli et al., 1996; Dominic et al., 1998). A compilation of published data on the response of nitrogen fixation to varying ambient $\mathrm{O}_{2}$ concentrations suggests a general relationship that is consistent with both the short term response of the enzyme to $\mathrm{O}_{2}$ and the organisms' longer evolutionary adaptations where $\mathrm{O}_{2}$ is used as sink for electrons in respiration (Fig. 1d). In Trichodesmium maximum nitrogen fixation occurs at oxygen concentrations of 2 to $5 \%$. In an anaerobic or mi-

BGD

2, 261-273, 2005

Nitrogenase controls $\mathrm{N}$ and $\mathbf{O}$ cycles

I. Berman-Frank et al.

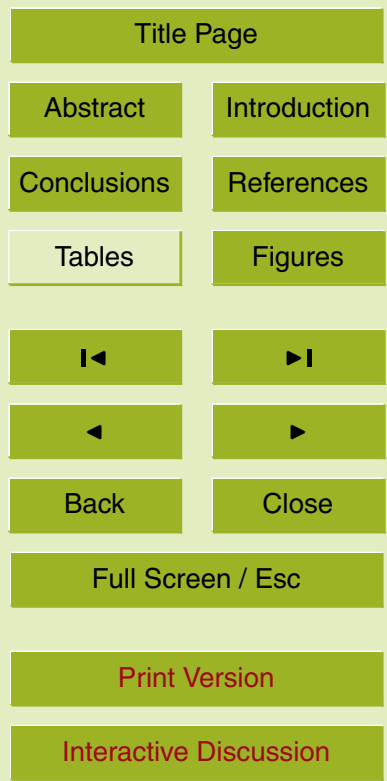

EGU 
croaerobic milieu, respiratory requirements are not met and substrates essential for nitrogen fixation are not produced, causing a decline in the enzyme's performance. As oxygen concentrations increase above $5 \%$, the enzyme activity is inhibited, with only $\sim 70 \%$ activity measured at atmospheric oxygen concentrations of $21 \%$. At oxygen 5 concentrations greater than $30 \%$, a sharp drop in activity reduces fixation efficiency (potential) to $<10 \%$ within minutes. This pattern of a "chronically crippled" nitrogenase is corroborated in data from other aerobic cyanobacteria such as Anabaena and Gloethece (Fig. 1d). In these cyanobacteria, lowering the oxygen below atmospheric concentrations also enhances relative nitrogenase activity at short durations (as in 10 Fig. 1c). However, at very low oxygen concentrations, respiratory performance and the production of energy and substrates for nitrogen fixation is affected, thus lowering nitrogen-fixation rates and the overall metabolic performance of Trichodesmium as we observed with the enhanced mortality and biomass crash under the prolonged exposure to the reduced oxygen concentrations (Fig. 2).

Nitrogenase may account from 10\% (Thorneley and Ashby, 1989) to 40\% (Jouanneau et al., 1985) of total cellular protein and is a significant sink for Fe in diazotrophs. Accordingly, the "chronic crippling" of the enzyme at PAL levels of $\mathrm{O}_{2}$ imposes a metabolic inefficiency that reflects an extraordinarily slow tempo of evolution for this critical biogeochemical process. The high conservation within the primary sequence of nif genes (Zehr et al., 1997b; Zehr et al., 2003; Raymond et al., 2004) indicates that the evolutionary risks associated with modifying nitrogenase outweigh the costs of its production. The inefficiency in nitrogenase is analogous to other core metabolic proteins, such as the reaction center protein of photosystem II, D1, and ribulose 1,5 bisphosphate carboxylase/oxygenase (Rubisco), which also evolved under anaerobic

conditions; all three either operate at a fraction of their capacities under ambient atmospheric conditions or undergo extremely high rates of turnover as a result of posttranslational damage. The inhibition of all of these proteins, either directly by elevated $\mathrm{O}_{2}$, or indirectly through reactive oxygen species, potentially exerts a strong biological control on the upper bound of the concentration of the gas in Earth's atmosphere.
BGD

2, 261-273, 2005

Nitrogenase controls $\mathrm{N}$ and $\mathbf{O}$ cycles

I. Berman-Frank et al.

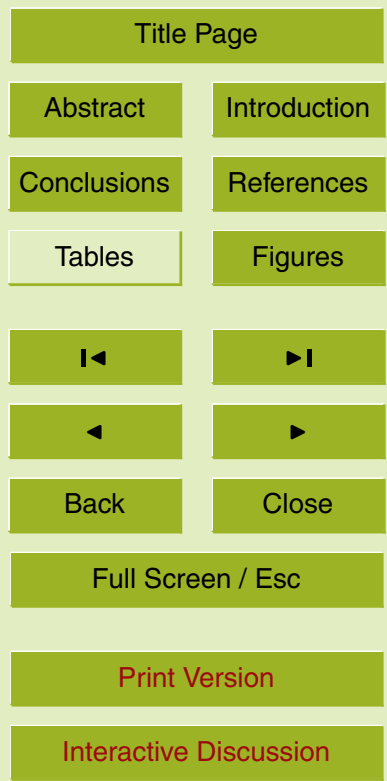

EGU 
Acknowledgements. Thanks for the nitrogenase antibodies generously provided by P. Ludden, University of California Berkley, and axenic Trichodesmium IMS101 from J. Waterburgh, WHOI. Funding was provided by the Center for Bioinorganic Chemistry NSF/CEBIC (NSF CHE 0221978) to PGF and GCD, NSF Biocomplexity Grant OCE 00-84032 to PGF, and a Rutgers 5 University Post-Doctoral fellowship to I. B.-F.

\section{References}

Bergman, B., Gallon, J. R., Rai, A. N., and Stal, L. J.: $\mathrm{N}_{2}$ fixation by non-heterocystous cyanobacteria, FEMS Microbiology reviews, 19, 139-185, 1997.

Berman-Frank, I., Cullen, J. T., Shaked, Y., Sherrell, R. M., and Falkowski, P. G.: Iron availability, 10 cellular iron quotas, and nitrogen fixation in Trichodesmium, Limnology and Oceanography, 46, 1249-1260, 2001a.

Berman-Frank, I., Lundgren, P., Chen, Y.-B., Kupper, H., Kolber, Z., Bergman, B., and Falkowski, P. G.: Segregation of Nitrogen Fixation and Oxygenic Photosynthesis in the Marine Cyanobacterium Trichodesmium, Science, 294, 1534-1537, 2001b.

15 Berman-Frank, I., Lundgren, P., and Falkowski, P. G.: Nitrogen fixation and photosynthetic oxygen evolution in cyanobacteria, Research in Microbiology, 154, 157-164, 2003.

Burgess, B. K. and Lowe, D. J.: Mechanism of molybdenum nitrogenase, Chemical Reviews, 96, 2983-3011, 1996.

Capone, D. G.: Determination of Nitrogenase Activity in Aquatic Samples Using the Acetylene

20 Reduction Procedure, in: Handbook of methods in aquatic microbial ecology, edited by: Kemp, P. F., Sherr, B., Sherr, E., and Cole, J., Lewis Publishers, New York, 621-631, 1993.

Chen, Y. B., Dominic, B., Mellon, M. T., and Zehr, J. P.: Circadian rhythm of nitrogenase gene expression in the diazotrophic filamentous nonheterocystous Cyanobacterium Trichodesmium sp strain IMS101, Journal of Bacteriology, 180, 3598-3605, 1998.

Chen, Y. B., Dominic, B., Zani, S., Mellon, M. T., and Zehr, J. P.: Expression of photosynthesis genes in relation to nitrogen fixation in the diazotrophic filamentous nonheterocystous cyanobacterium Trichodesmium sp. IMS 101, Plant Molecular Biology, 41, 89-104, 1999.

Dominic, B., Chen, Y.-B., and Zehr, J. P.: Cloning and transcriptional analysis of the nifUHDK genes of Trichodesmium sp. IMS101 reveals stable nifD, nifDK, and nifK transcripts, Microbiology, 144, 3359-3368, 1998.

BGD

2, 261-273, 2005

Nitrogenase controls $\mathrm{N}$ and $\mathrm{O}$ cycles

I. Berman-Frank et al.

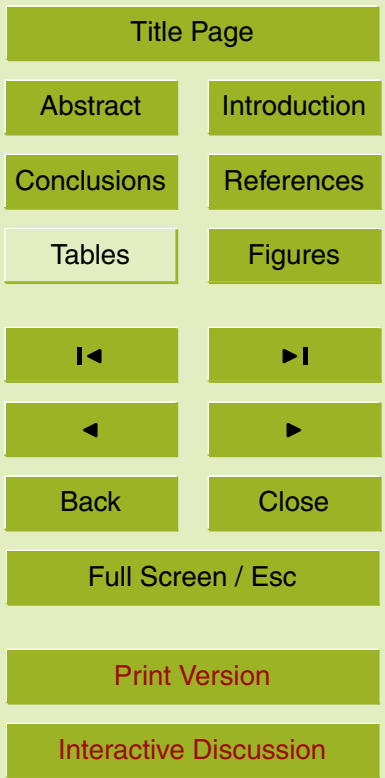

EGU 
Durner, J., Bohm, I., Knorzer, O. C., and Boger, P.: Proteolytic degradation of dinitrogenase reductase from Anabaena variabilis (ATCC 29413) as a consequence of ATP depletion and impact of oxygen, Journal of Bacteriology, 178, 606-610, 1996.

Elhai, J. and Wolk, C. P.: Hierarchical control by oxygen in heterocysts of Anabaena, paper presented at VIth International symposium on Photosynthetic Prokaryotes, 1991.

Ernst, A., Liu, Y.-D., Reich, S., and Boger, P.: Diurnal modification in the cyanobacterium Anabaena variabilis, Botanica Acta, 103, 183-189, 1990.

Falkowski, P. G.: Evolution of the nitrogen cycle and its influence on the biological sequestration of $\mathrm{CO}_{2}$ in the ocean, Nature, 387, 272-275, 1997.

10 Gallon, J. R.: Reconciling the incompatible: $\mathrm{N}_{2}$ fixation and Oxygen, New Phytologist, 122, 571-609, 1992.

Gallon, J. R., Pederson, D. M., and Smith, G. D.: The effect of temperature on the sensitivity of nitrogenase to oxygen in the cyanobacteria Anabaena cylindrica (Lemmermann) and Gloeothece (Nageli), New Phytologist, 124, 251-257, 1993.

Hallenbeck, P. C.: Mutations affecting nitrogenase switch-off in Rhodobacter capsulatus, Biochimica et Biophysica Acta (BBA) - Protein Structure and Molecular Enzymology, 1118, 161-168, 1992.

Jouanneau, Y., Meyer, C. M., and Vignais, P. M.: Regulation of nitrogenase activity through iron protein interconversion into an active and an inactive form in Rhodopseudomonas capsulata, Biochimica et Biophysica Acta (BBA) - Protein Structure and Molecular Enzymology, 749, 318-328, 1983.

Jouanneau, Y., Wang, B., and Vignais, P. M.: Stimulation by light of nitrogenase synthesis in cells of Rhodopseudomonas capsulata growing in $\mathrm{N}$-limited continuous cultures, Biochimica et Biophysica Acta, 808, 149-155, 1985.

Kustka, A., Sanudo-Wilhelmy, S., Carpenter, E. J., Capone, D. G., and Raven, J. A.: A revised estimate of the iron use efficiency of nitrogen fixation, with special reference to the marine cyanobacterium Trichodesmium spp. (Cyanophyta), Journal of Phycology, 39, 12-25, 2003.

Ludden, P. W. and Roberts, G. P.: The biochemistry and genetics of nitrogen fixation by photosynthetic bacteria, in: Anoxygenic photosynthetic bacteria, edited by: Blankenship, R. E.,

so Madigan, M. T., and Bauer, C. E., Kluwer Academic Publishers, The Netherlands, 929-947, 1995.

Mague, T. H., Mague, F. C., and Holm-Hansen, O.: Physiology and Chemical composition of nitrogen-fixing phytoplankton in the central north pacific ocean, Marine Biology, 41, 213-227,

Nitrogenase controls $\mathrm{N}$ and $\mathrm{O}$ cycles

I. Berman-Frank et al.

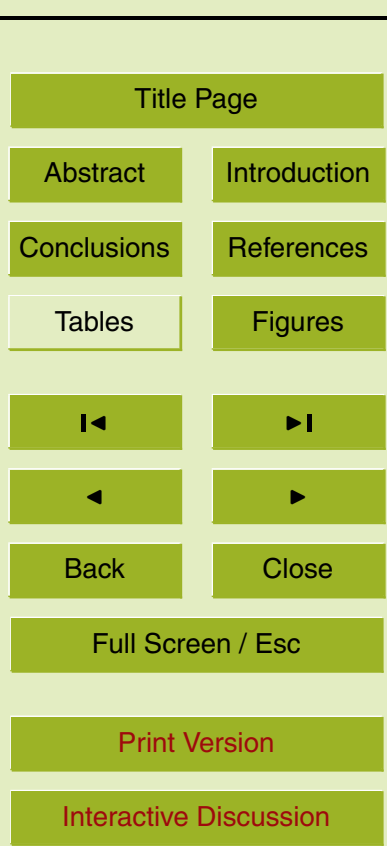


1977.

Ohki, K., and Fujita, Y.: Aerobic nitrogenase activity measured as acetylene reduction in the marine non-heteerocystous cyanobacterium Trichodesmium spp. grown under artificial conditions, Marine Biology, 91, 9-13, 1988.

5 Ohki, K., Zehr, J. P., Falkowski, P. G., and Fujita, Y.: Regulation of nitrogen-fixation by different nitrogen sources in the marine non-heterocystous cyanobacterium Trichodesmium sp. NIBB1067, ARch Microbiol., 156, 335-337, 1991.

Pan, B. and Vessey, J. K.: Response of the endophytic diazotroph Gluconacetobacter diazotrophicus on solid media to changes in atmospheric partial $\mathrm{O}_{2}$ pressure, Appl. Environ.

10 Microbiol., 67, 4694-4700, 2001.

Prosperi, C. H.: A cyanophyte capable of fixing nitrogen under high-levels of oxygen, Journal of Phycology, 30, 222-224, 1994.

Raven, J. A.: The iron and molybdenum use efficiencies of plant growth with different energy, carbon and nitrogen sources, New Phytologist, 109, 279-287, 1988.

15 Raymond, J., Siefert, J. L., Staples, C. R., and Blankenship, R. E.: The natural history of nitrogen fixation, Molecular Biology and Evolution, 21, 541-554, 2004.

Saino, T. and Hattori, A.: Aerobic nitrogen fixation by the marine non-heterocystous cyanobacterium Trichodesmium (Oscillatoria) spp.: its protective mechanism against oxygen, Marine Biology, 70, 251-254, 1982.

20 Sweet, W. J. and Burris, R. H.: Effects of in vivo treatments on the activity of nitrogenase isolated from Rhodospirillum rubrum, Biochimica et Biophysica Acta (BBA) - Bioenergetics, 680, 17-21, 1982.

Thorneley, R. N. F. and Ashby, G. A.: Oxidation of nitrogenase iron protein by dioxygen without inactivation could contribute to high respiration rates of Azotobacter species and facilitate nitrogen fixation in aerobic environments., Biochem J., 261, 181-187, 1989.

Tuli, R., Naithani, S., and Misra, H. S.: Cyanobacterial photosynthesis and the problem of oxygen in nitrogen-fixation: A molecular genetic view, Journal of Scientific \& Industrial Research, 55, 638-657, 1996.

Yakunin, A. F., Fedorov, A. S., Laurinavichene, T. V., Glaser, V. M., Egorov, N. S., Tsygankov, A. 30 A., Zinchenko, V. V., and Hallenbeck, P. C.: Regulation of nitrogenase in the photosynthetic bacterium Rhodobacter sphaeroides containing draTG and nifHDK genes from Rhodobacter capsulatus, Canadian Journal of Microbiology, 47, 206-212, 2001.

Zehr, J., Wyman, M., Miller, V., Duguay, L., and Capone, D. G.: Modification of the Fe protein

Nitrogenase controls $\mathrm{N}$ and $\mathrm{O}$ cycles

I. Berman-Frank et al.

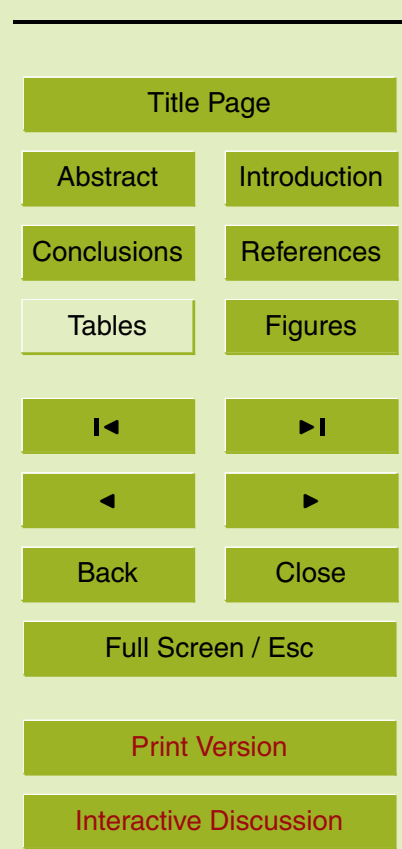

EGU 
of nitrogenase in Natural populations of Trichodesmium thiebautii, Appl. Environ. Microbiol., 59, 669-676, 1993.

BGD

Zehr, J. P., Harris, D., Dominic, B., and Salerno, J.: Structural analysis of the Trichodesmium nitrogenase iron protein: implications for aerobic nitrogen fixation activity, FEMS Microbiology letters, 153, 303-309, 1997a.

Zehr, J. P., Jenkins, B. D., Short, S. M., and Steward, G. F.: Nitrogenase gene diversity and microbial community structure: a cross-system comparison, Environmental Microbiology, 5, 539-554, 2003.

Zehr, J. P., Mellon, M. T., and Hiorns, W. D.: Phylogeny of cyanobacterial nifH genes: Evolutionary implications and potential applications to natural assemblages, Microbiology-UK, 143, 1443-1450, 1997b.

2, 261-273, 2005

Nitrogenase controls $\mathbf{N}$ and $\mathbf{O}$ cycles

I. Berman-Frank et al.

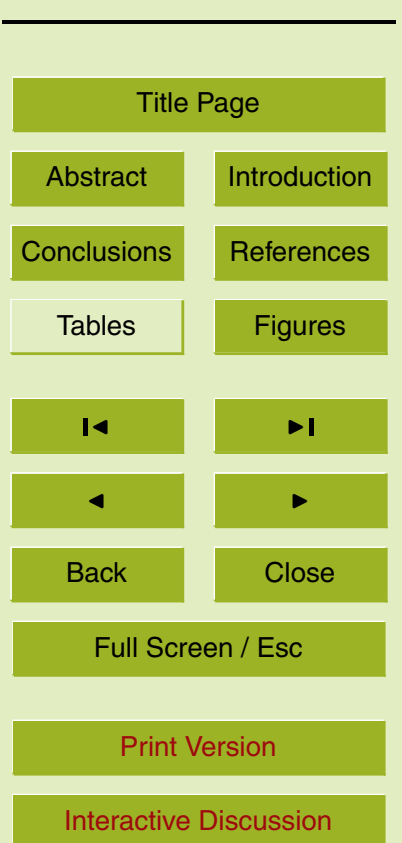

EGU 


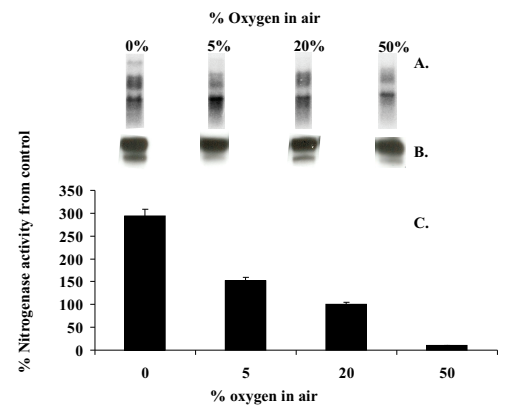

BGD

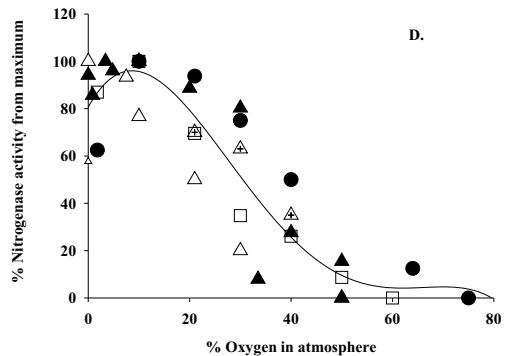

2, 261-273, 2005

Nitrogenase controls $\mathrm{N}$ and $\mathbf{O}$ cycles

I. Berman-Frank et al.

Fig. 1. (a) nifHDK transcript abundance for Trichodesmium IMS101 cultures bubbled with nitrogen ( $0 \%$ oxygen), $5 \%, 20 \%$, and $50 \% \mathrm{O}_{2}$ for $5 \mathrm{~h}$. (b) Western blots of nitrogenase protein abundance (challenged with universal Fe-protein polyclonal antibodies) for the above experiment (c). Nitrogenase activity (presented as \% of air-control) measured by acetylene reduction for the above experiment $1 \mathrm{~h}$ after induction of bubbling. (d) Relationship between $\mathrm{O}_{2}$ concentrations and nitrogen fixation (\% from maximum rates) for Trichodesmium IMS101 and other diazotrophs. Filled triangles: experimental data from our cultures of Trichodesmium IMS101; empty triangles with cross - Trichodesmium NIBB1067 (Ohki and Fujita, 1988), empty triangles - Trichodesmium spp. field populations (Mague et al., 1977; Saino and Hattori, 1982), black circles - Anabaena cylindrical Gallon et al., 1993), black squares - Gloeothece (Nageli) (Gallon et al., 1993). Short term (1-2h) anaerobic incubation yields maximum nitrogenase activity for aerobic diazotrophs (Fig. 1c). Under prolonged exposure, respiratory requirements are essential and yield maximum nitrogenase activity (in vivo) at microaerobic oxygen concentrations.

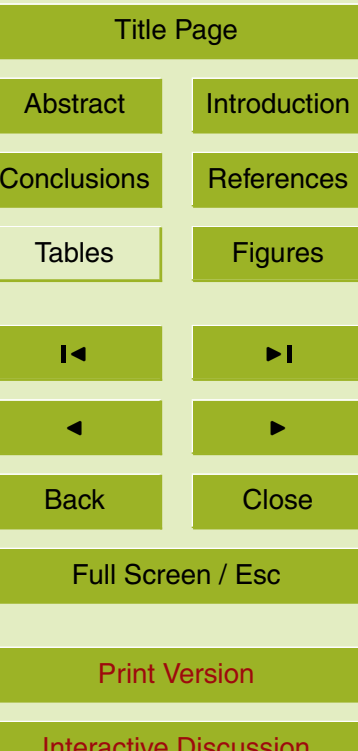




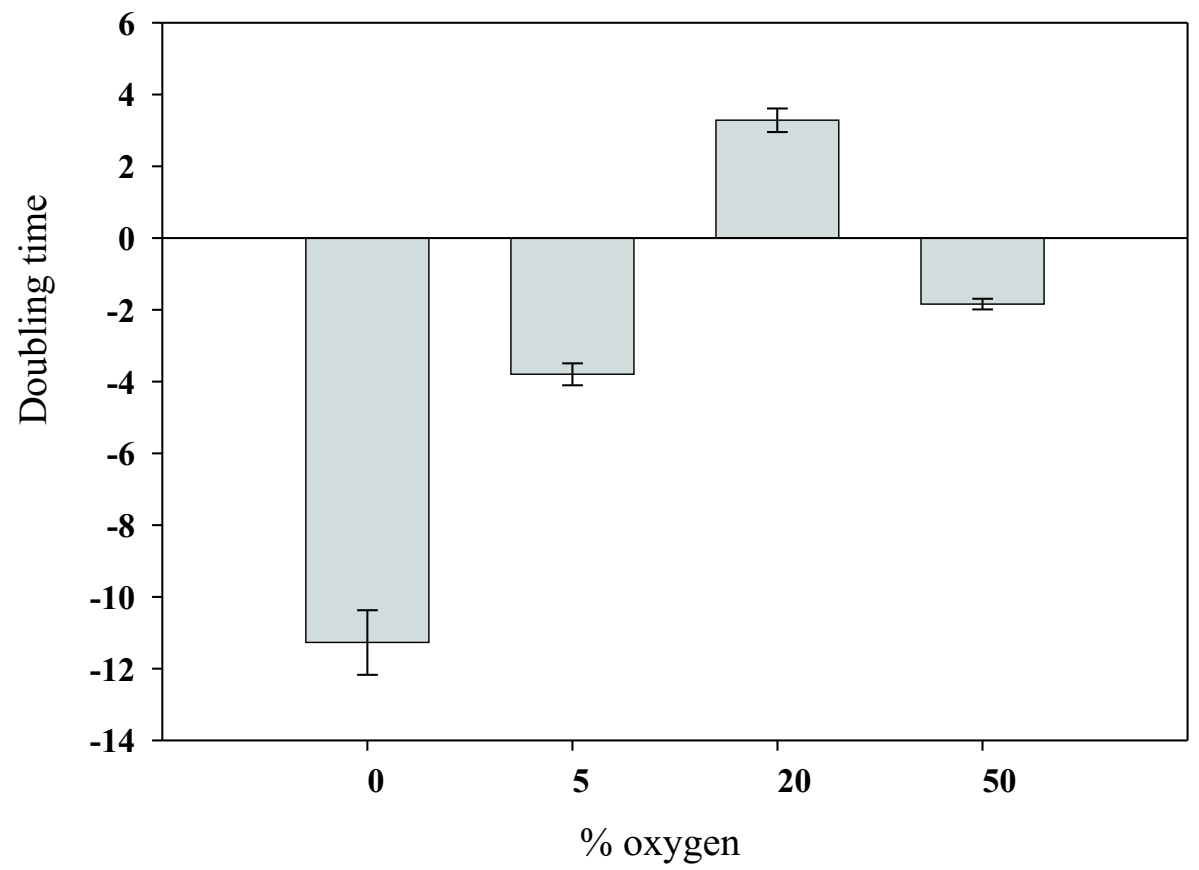

Fig. 2. Effects of varying oxygen concentration on Trichodesmium IMS101 growth. Cultures grown under air were transferred to different oxygen concentrations $\left(+0.035 \% \mathrm{CO}_{2}+\right.$ balance $\mathrm{N}_{2}$ ) and incubated for $72 \mathrm{~h}$ under these conditions. Carbon specific growth or mortality rates (doubling times - days) were determined for cultures after 3 days. Negative growth or biomass decline was measured for all cultures except those under air. Error bars are standard deviations from the average of 3 replicate bottles per treatment.
2, 261-273, 2005

Nitrogenase controls $\mathrm{N}$ and $\mathbf{O}$ cycles

I. Berman-Frank et al.

Title Page

Abstract Introduction

Conclusions

References

Tables

Figures

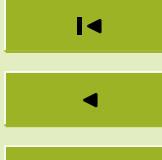

Back

Close

Full Screen / Esc

Print Version

Interactive Discussion 